Article

\title{
The Role of Foaming Agent and Processing Route in the Mechanical Performance of Fabricated Aluminum Foams
}

Alexandra Byakova ${ }^{1, *}$, Svyatoslav Gnyloskurenko ${ }^{2}$ and Takashi Nakamura ${ }^{3}$

1 Institute for Problems of Materials Science, National Academy of Sciences of Ukraine, 3 Krzhyzhanovsky Street, Kiev 03142, Ukraine

2 Physical-Technological Institute of Metals and Alloys, National Academy of Sciences of Ukraine, Kiev 04004, Ukraine; E-Mail: slava.vgn@gmail.com

3 Institute of Multidisciplinary Research for Advanced Materials, Tohoku University, Sendai 980-8577, Japan; E-Mail: ntakashi@tagen.tohoku.ac.jp

* Author to whom correspondence should be addressed; E-Mail: byakova@mail.ru; Tel./Fax: +38-044-423-82-53.

Received: 30 March 2012; in revised form: 30 April 2012 / Accepted: 9 May 2012 / Published: 23 May 2012

Abstract: The results of the present study highlight the role of foaming agent and processing route in influencing the contamination of cell wall material by side products, which, in turn, affect the macroscopic mechanical response of closed-cell Al-foams. Several kinds of Al-foams have been produced with pure Al by the Alporas melt process and powder metallurgical technique, all performed either with conventional $\mathrm{TiH}_{2}$ foaming agent or $\mathrm{CaCO}_{3}$ as an alternative. Mechanical characteristics of contaminating products induced by processing additives, all of which were presented in one or another kind of Al-foam, have been determined in indentation experiments. Damage behavior of these contaminations affects the micro-mechanism of deformation and favors either plastic buckling or brittle failure of the cell walls. It is justified that there is no discrepancy between experimental values of compressive strengths for Al-foams comprising ductile $\mathrm{Al}+\mathrm{Al}_{4} \mathrm{Ca}$ eutectic domains and those prescribed by theoretical models for closed-cell structure. However, the presence of low ductile $\mathrm{Al}+\mathrm{Al}_{3} \mathrm{Ti}+\mathrm{Al}_{4} \mathrm{Ca}$ eutectic domains and brittle particles/layers of $\mathrm{Al}_{3} \mathrm{Ti}$, fine $\mathrm{CaCO}_{3} / \mathrm{CaO}$ particles, $\mathrm{Al}_{2} \mathrm{O}_{3}$ oxide network, and, especially, residues of partially reacted $\mathrm{TiH}_{2}$, results in reducing the compressive strength to values close to or even below those of open-cell foams of the same relative density. 
Keywords: Al-based foams; foaming agents; processing; cell wall constituents; mechanical properties

\section{Introduction}

The unique combination of low specific weight and novel mechanical and physical properties of aluminum foams offer significant performance gains and have generated a growing interest in the development of light, stiff structures for different engineering applications. In particular, closed cell Al-foams show a capacity to undergo large strains (up to 60-70\%) under almost constant stress, ensuring their remarkable ability to absorb impact energy, making them attractive for different applications where effective utilization of impact energy is required. For instance, in aluminum foam sandwich (AFS) structures composed of metal/ceramic coversheets and Al-foam core, the last one can act as an efficient impact energy absorber that limits accelerations in crash accidents, providing crash protection for terrestrial and marine vehicles [1,2]. That is why there has been extensive interest recently in the production [3-10] and mechanical performance of Al-foams [11-19], as well as composite layered structures, incorporating a Al-foam core [3,20,21].

Several models [3,22-24], based on an idealized representation of cellular structure, have been developed for interpreting the mechanical behavior of foams. However, the actual profile of mechanical properties for real Al-foams is far removed from theoretical predictions based on idealized representations of defect-free cellular materials [11,23]. It is commonly considered that disagreements between experimental results and theoretical predictions arise due to different imperfections existing in real metallic foams. Usually, cell morphology [17,23,25,26], micro-pores, and their spatial distribution in cell walls [16], as well as non-homogeneous density distribution [24,25], are considered to be the key factors in control of mechanical behavior of aluminum foams. However, it is difficult to quantify the precise significance of these factors because of microscopic features such as foreign particles, precipitates, and solute elements present in the cell wall material, currently thought to be of great importance, resulting in the non-homogeneous stress/strain distribution. Nevertheless, microstructural aspects are still largely ignored in most studies, despite the known crucial role of microstructure performance characteristics of the corresponding bulk material. This problem becomes increasingly pronounced when the processing of additives, usually resulting in unconventional alloys $[8,11-13,19]$, is taken into consideration. Great number of various intermetallic compounds and other foreign particles formed in the course of the foaming process substantially affect the micromechanism of deformation, degrading the mechanical response of foams [12,13,16,18,19]. Unfortunately, evidence concerning the mechanical response of Al-based intermetallic compounds and other particles, typical for the cell wall material of aluminum foams, are few in number [19,27].

The intent of the present paper is to elucidate the role of foaming agent and processing route in influencing the mechanical performance of Al-foams. Attention is primarily concentrated on the correlation between the macroscopic compressive behavior of Al-foam and characteristic features for mechanical response of the cell wall constituents induced by processing additives. 


\section{Results and Discussion}

\subsection{Material Characterization}

All kinds of Al-foams (F1 and F2) fabricated by the melt processing Alporas route exhibit typical closed-cells of spherical shape, although another outcome was true for Al-foams (F3 and F4) performed by the powder metallurgical (PM) route using powder compact precursor. Cells created from powder compacts displayed an elliptic-like shape with the major axis arranged along the extrusion direction. Anisotropy of the cell shape for PM Al-foams was found to be dependent on extrusion conditions and, especially, on the reduced coefficient, $k_{\mathrm{e}}[12,18]$. In the present study, PM Al-foams (F3 and F4) composed of cells with aspect ratios 1.1 (F3) and 1.4 (F4) were produced and chosen for further experimentation. An additional difference concerns the fact that the mean cell size of carbonate foams (F2 and F4) was found to be smaller at least by a factor of 2 compared to that of hydride foams (F1 and F3). All kinds of Al-foams demonstrate non-homogeneous cell wall material microstructure, as shown in Figure 1.

Figure 1. SEM images of the cell walls for Al-foams produced with pure Al by (a,b) Alporas melt process and (c,d) powder metallurgical technique, all performed either with (a,c) $\mathrm{TiH}_{2}$ foaming agent or $(\mathbf{b}, \mathbf{d}) \mathrm{CaCO}_{3}$ foaming agent.

(a)

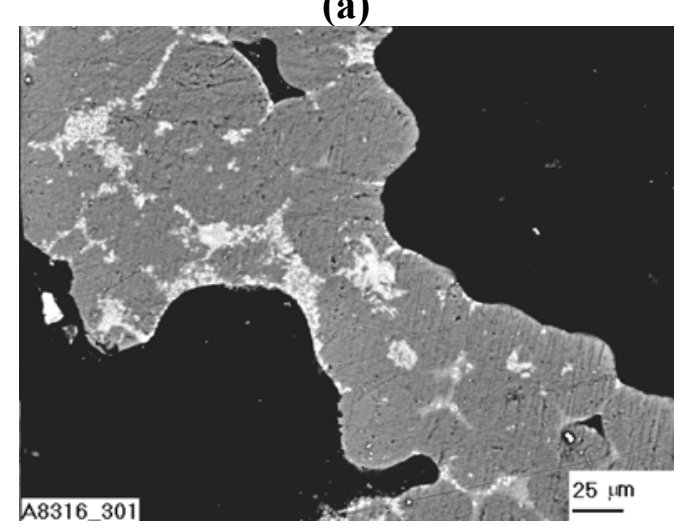

(c)

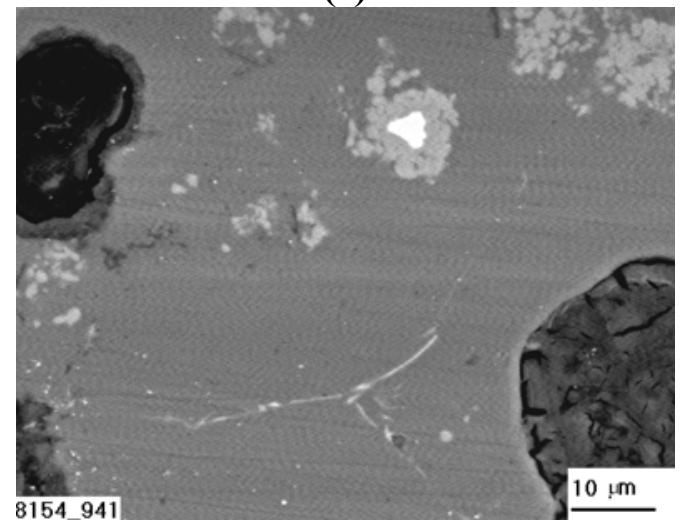

(b)

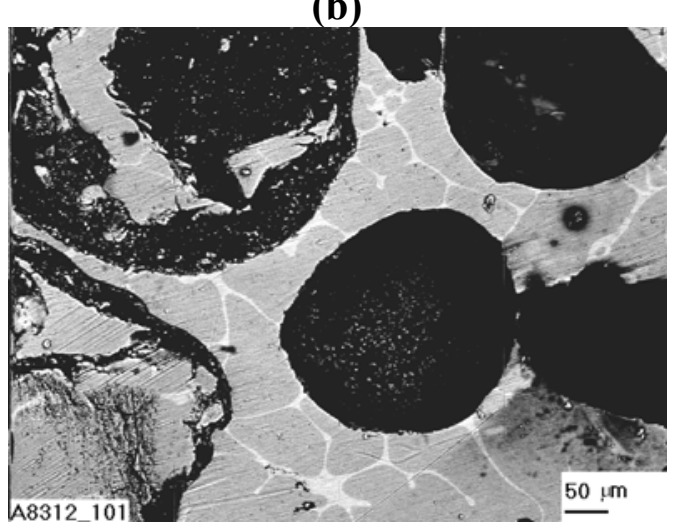

(d)

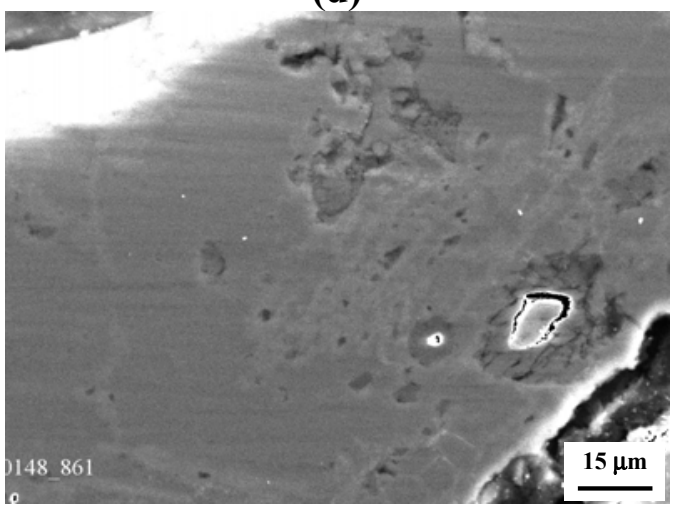

Nevertheless, cell wall constituents revealed in hydride and carbonate kinds of Al-foams are rather different and dependent on the processing technique and processing additives, as listed in Table 1. As originally reported in $[12,14,18,19]$, the cell wall material of Al-foams (F1 and F2) processed via the 
Alporas route comprises coarse $\mathrm{Al}$ dendrites rounded by a network of eutectic domains with composition dependent on the kind of foaming agent, $\mathrm{TiH}_{2}$ or $\mathrm{CaCO}_{3}$. As can be seen in Figures $1(\mathrm{a}, \mathrm{b})$, the hydride kind of $\mathrm{Al}$-foam (F1) contains $\mathrm{Al}+\mathrm{Al}_{4} \mathrm{Ca}+\mathrm{Al}_{3} \mathrm{Ti}$ eutectic domains (light grey), whereas $\mathrm{Al}+\mathrm{Al}_{4} \mathrm{Ca}$ eutectic domains (light grey) are indicative of a carbonate kind of Al-foam (F2). In addition, incorporated Al-Ca-Ti particles (white) are found in the cell wall material of the hydride kind of Al-foam (F1), making the fraction volume of foreign constituents greater compared to that of $\mathrm{CaCO}_{3}$-foam. Moreover, increased content (roughly about 0.26 at.\%) of dissolved $\mathrm{Ti}$ is detected by energy dispersive spectroscopy in the Al matrix of the hydride kind of Al-foam (F1).

As can be seen in Figure 1(c,d), huge numbers of foreign particles of partly converted foaming agents and/or their reaction products are randomly scattered in the cell walls of the Al-foams (F3 and F4) performed by the PM route. Small $\mathrm{Al}_{3}$ Ti particles (light grey) and Ti-rich particles (white) rounded by $\mathrm{Al}_{3} \mathrm{Ti}$ layers (light grey) are indicative of a hydride kind of Al-foam (F3), as shown in Figure 1c. In addition, trace amount of $\mathrm{Al}+\mathrm{Al}_{3} \mathrm{Ti}$ eutectic domains (light grey) are revealed within the cell walls of this kind of $\mathrm{Al}$-foam. Network of $\mathrm{Al}_{2} \mathrm{O}_{3}$ (light grey) being a side product of a broken oxide layer, which always covers the $\mathrm{Al}$ powder particles, is also contained by the cell wall material, as can be seen in Figure 1d. Compared to the hydride kind of Al-foam (F3), CaO particles (white) entrapped by $\mathrm{Al}_{2} \mathrm{O}_{3}$ network are found in the cell wall material of the carbonate kind of Al-foam (F4), as shown in Figure 1d. Actually, few partly decomposed $\mathrm{CaCO}_{3}$ particles (dark grey) are also expected within the cell wall material. These particles can survive in the cell wall material because of the slow kinetics of $\mathrm{CaCO}_{3}$ decomposition [7,10]. As a general conclusion, it could be assumed that pronounced differences in the cell wall microstructure results from the difference in processing route and processing additives, as evidenced from Table 1.

Table 1. Characteristic features of the cell wall material created in Al-foams.

\begin{tabular}{ccc}
\hline Code & Process & Cell wall constituents \\
\hline F1 & Alporas route & $\mathrm{Al}+\left(\mathrm{Al}+\mathrm{Al}_{3} \mathrm{Ti}+\mathrm{Al}_{4} \mathrm{Ca}\right)$ domains $+\mathrm{Al}-\mathrm{Ca}-\mathrm{Ti}$ particles \\
F2 & Alporas route & $\mathrm{Al}+\left(\mathrm{Al}+\mathrm{Al}_{4} \mathrm{Ca}\right)$ domains \\
F3 & PM technique & $\mathrm{Al}+$ particles: $\mathrm{Al}_{3} \mathrm{Ti}, \mathrm{TiH}_{2} / \mathrm{Al}_{3} \mathrm{Ti}, \mathrm{Al}_{2} \mathrm{O}_{3}$ \\
F4 & PM technique & $\mathrm{Al}+$ particles: $\mathrm{CaO}, \mathrm{CaCO}_{3}, \mathrm{Al}_{2} \mathrm{O}_{3}$ \\
\hline
\end{tabular}

\subsection{Mechanical Properties and Damage Behavior of Cell Wall Constituents}

The set of mechanical characteristics determined for the materials studied compositionally corresponded to the cell wall constituents that have been revealed in the hydride and carbonate kinds of Al-foams, and are listed in Table 2.

Several aspects should be mentioned here by comparison with the data listed in Table 2. First of all it could be concluded that the presence of solute $\mathrm{Ti}$ in the Al matrix of the cell walls for hydride kinds of Al-foams (F1 and F3) causes Young's modulus, $E$, and nanohardness, $H_{h}$, to rise. Titanium hydride, $\mathrm{TiH}_{1.92}$, and $\mathrm{Al}_{4} \mathrm{Ca}$ intermetallic compound give the values of Young's modulus, $E$, and yield strength, $\sigma_{y s}$, smaller than those for Al matrix, despite the fact that hardness numbers, $H_{h}$ and $H V$, are much higher. Another fact is true for the other cell wall constituents and solid materials, i.e., all of them 
exhibit much higher values of strength parameters such as $E, H_{h}, H V$, and $\sigma_{y s}$, compared to those indicative of Al matrix alloy. The second aspect concerns the difference in plasticity behavior of the cell wall constituents and other solid materials being formed in the cell walls under the influence of different processing additives. Only $\mathrm{Al}+\mathrm{Al}_{4} \mathrm{Ca}$ eutectic domains demonstrate quite high plasticity close to the Al matrix $\left(\delta_{H} \geq 0.9\right)$, suggesting ductile behavior of material under conventional tests under tensile and bending forces [28]. The opposite is true for $\mathrm{Al}+\mathrm{Al}_{4} \mathrm{Ca}+\mathrm{Al}_{3} \mathrm{Ti}$ domains and other solid materials, for which plasticity characteristics are smaller than the critical value, i.e., $\delta_{A} / \delta_{H}<0.9$, suggesting their low ductility and tendency to failure by ductile and/or brittle fracture. Figure 2 shows representative SEM images of the brittle microcracks within and around the microindentations placed on $\mathrm{Al}_{3} \mathrm{Ti}$ and $\mathrm{Al}_{4} \mathrm{Ca}$.

Table 2. Mechanical characteristics of the cell wall constituents and solid materials.

\begin{tabular}{|c|c|c|c|c|c|c|}
\hline Material/Foam Code & $\begin{array}{l}E, \\
\text { GPa }\end{array}$ & $\begin{array}{l}H_{h}, \\
\text { GPa }\end{array}$ & $\begin{array}{l}H V, \\
\text { GPa }\end{array}$ & $\delta_{A} / \delta_{H}$ & $\begin{array}{l}\sigma_{y s}, \\
\text { GPa }\end{array}$ & $\begin{array}{l}K_{1 c}, \\
\mathbf{M P a} \times \mathbf{m}^{1 / 2}\end{array}$ \\
\hline$\alpha-\mathrm{Al}_{\mathrm{Ti}} / \mathrm{F} 1, \mathrm{~F} 3$ & $97.0 \pm 10$ & $1.05 \pm 0.18$ & 0.40 & $0.94 / 0.96$ & - & - \\
\hline$\alpha-\mathrm{Al} / \mathrm{F} 2, \mathrm{~F} 4$ & $74.0 \pm 3$ & $0.54 \pm 0.0$ & $0.25 \pm 0.01$ & $0.96 / 0.97$ & $0.40^{*}$ & - \\
\hline$\left(\mathrm{Al}+\mathrm{Al}_{4} \mathrm{Ca}+\mathrm{Al}_{3} \mathrm{Ti}\right) / \mathrm{F} 2, \mathrm{~F} 3$ & $116 \pm 17$ & $5.51 \pm 1.27$ & - & $0.72 /-$ & - & - \\
\hline$\left(\mathrm{Al}+\mathrm{Al}_{4} \mathrm{Ca}\right) / \mathrm{F} 1$ & $79 \pm 7$ & $1.32 \pm 0.15$ & - & $0.90 /-$ & - & - \\
\hline $\mathrm{Al}_{3} \mathrm{Ti} / \mathrm{F} 1, \mathrm{~F} 3$ & $220.0 \pm 7$ & $8.9 \pm 0.9$ & $5.3 \pm 0.3$ & $0.72 / 0.78$ & 0.90 & $1.71 \pm 0.18$ \\
\hline $\mathrm{Al}_{4} \mathrm{Ca} / \mathrm{F} 2$ & $39.4 \pm 1.4$ & $2.2 \pm 0.1$ & $1.7 \pm 0.06$ & $0.64 / 0.63$ & 0.28 & $0.78 \pm 0.09$ \\
\hline $\mathrm{TiH}_{1.92} / \mathrm{F} 1, \mathrm{~F} 3$ & $40.5 \pm 0.2$ & $1.82 \pm 0.16$ & $1.32 \pm 0.05$ & $0.72 / 0.78$ & 0.21 & $0.71 \pm 0.01$ \\
\hline $\mathrm{CaCO}_{3} / \mathrm{F} 4$ & $79.0 \pm 1$ & $2.2 \pm 0.1$ & $1.60 \pm 0.05$ & $0.77 / 0.79$ & 0.79 & $0.52 \pm 0.20$ \\
\hline $\mathrm{CaO} / \mathrm{F} 4$ & $181^{* *}$ & - & $6.05^{* *}$ & $-/ 0.67$ & - & - \\
\hline $\mathrm{Al}_{2} \mathrm{O}_{3} / \mathrm{F} 3, \mathrm{~F} 4$ & $403.9^{* *}$ & - & 25 & $-/ 0.47$ & - & $4.0 \pm 0.15$ \\
\hline Technical Glass & 61 & - & $5.25 \pm 0.03$ & $-/ 0.29$ & - & $1.17 \pm 0.09$ \\
\hline
\end{tabular}

Note: $E, H_{h}, H V, \sigma_{y s}$, and $K_{l c}$, are Young's modulus, nanohardness, Vickers hardness, yield strength, and fracture toughness criterion, respectively; dimensionless parameters such as $\delta_{H}$ and $\delta_{A}$, are plasticity characteristics that define ductility of materials determined by indentation experiments, i.e., $\delta_{H}$ represents the part of plastic deformation in total deformation under microindentation, whereas $\delta_{A}$ represents the part of plastic deformation work in total deformation work during load-displacement experiments; * data are adopted over [4]; ** data are adopted over [29].

Figure 2. SEM images of indentations placed on (a) $\mathrm{Al}_{4} \mathrm{Ca}$ and (b) $\mathrm{Al}_{3} \mathrm{Ti}$ under indentation loads such as (a) $\mathrm{F}=1.0 \mathrm{~N}$ and (b) $\mathrm{F}=1.5 \mathrm{~N}$ by using trihedral indenter with the angle at the tip $55^{\circ}$.

(a)

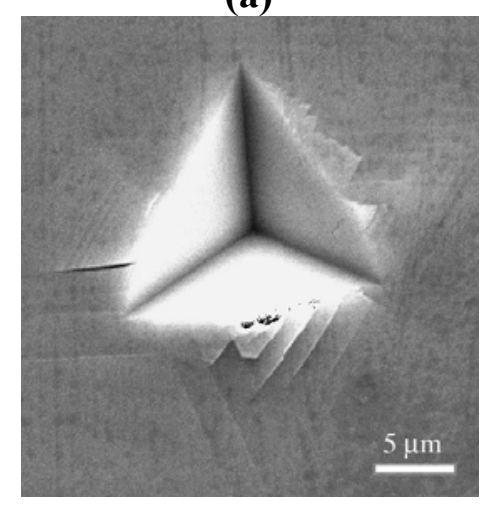

(b)

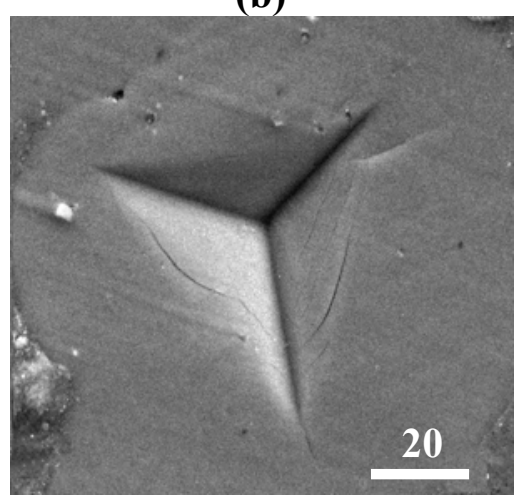


In addition, several systems for dislocation gliding inclined one towards the other are revealed around microindentations placed on the $\mathrm{Al}_{3} \mathrm{Ti}$ intermetallic compound. Slight slip bands indicative of dislocation activity are also visible around microindentations placed on the $\mathrm{Al}_{4} \mathrm{Ca}$ intermetallic compound.

Nanoindentation data give additional information on the damage behavior of low ductile solid materials. Unlike titanium hydride $\mathrm{TiH}_{1.92}$, for which nanoindentation diagrams are mostly typical of regular elastoplastic materials, a huge number of displacement discontinuities (pop-ins), indicative of localized deformation in share bands, are revealed in the load-displacement curves for $\mathrm{Al}_{3} \mathrm{Ti}$ intermetallic compound and marble, $\mathrm{CaCO}_{3}$, as shown in Figure 3.

It is commonly considered that strong localized deformation is accompanied by extrusion and intrusion processes, finally resulting in crack nucleation. The result of these processes is clearly visible in Figure 2a.

Figure 3. Load displacement curves recorded in nanoindentation experiments for (a) $\mathrm{Al}_{4} \mathrm{Ca}$ (1) and $\mathrm{TiH}_{1.92}$ (2); as well as for (b) $\mathrm{Al}_{3} \mathrm{Ti}$ (1) and $\mathrm{CaCO}_{3}$ (2).

(a)

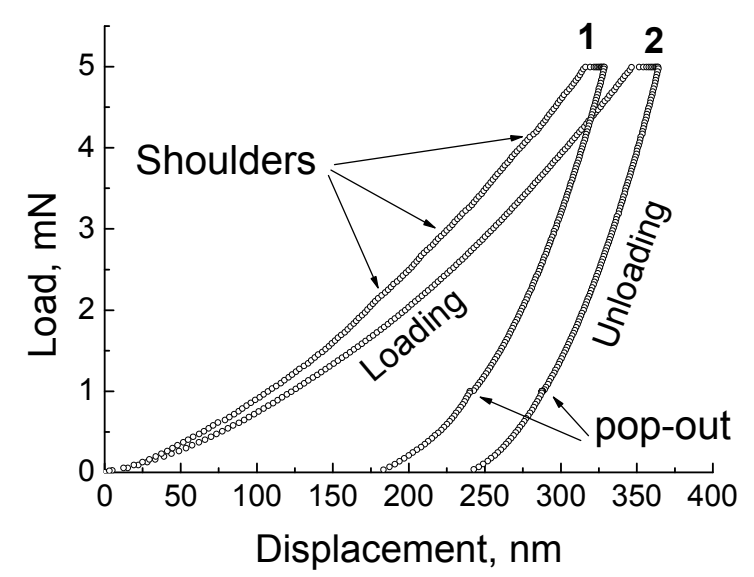

(b)

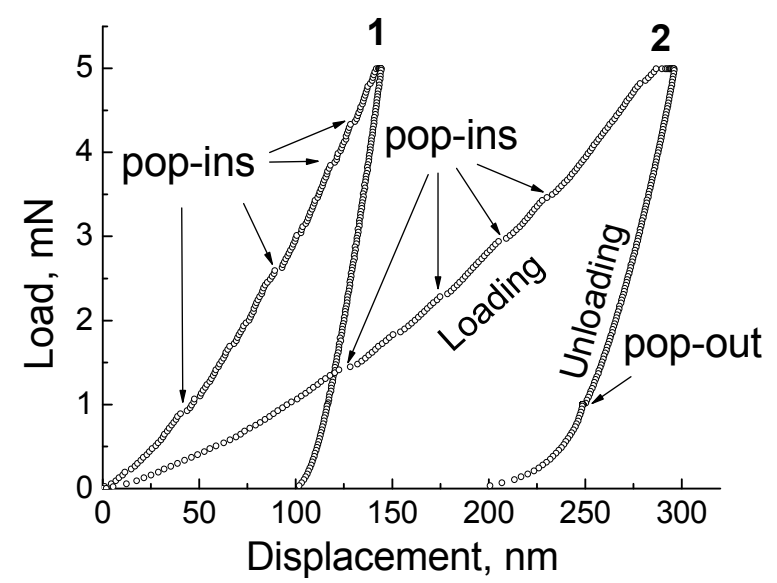

Compared to $\mathrm{Al}_{3} \mathrm{Ti}$ compound, the loading part of the load-displacement curve for $\mathrm{Al}_{4} \mathrm{Ca}$ intermetallic compound given in Figure 3a is fairly featureless. Nonetheless, shoulders, which are very small to be readily seen, could be recognized in the load-displacement curve for $\mathrm{Al}_{4} \mathrm{Ca}$ intermetallic compound. The same as pop-ins, these small shoulders are usually ascribed either to microcracking within indentation or to dislocation activity [30]. The latter is indicative of $\mathrm{Al}_{4} \mathrm{Ca}$ intermetallic compound, as can be seen in Figure 2b.

Thus, both kinds of intermetallic compounds $\left(\mathrm{Al}_{4} \mathrm{Ca}, \mathrm{Al}_{3} \mathrm{Ti}\right)$, which are of tremendous importance in foaming processes, show a significant tendency to failure due to mechanical damage. The difference is that the mechanical damage of $\mathrm{Al}_{3} \mathrm{Ti}$ intermetallic compound is dominated by ductile cleavage, superimposed by brittle fracture, while mechanical damage of $\mathrm{Al}_{4} \mathrm{Ca}$ intermetallic compound is primarily caused by brittle fracture that is accompanied by confined plastic flow in order to partially accommodate high strains in the surrounding material.

In addition, nanoindentation data for marble, $\mathrm{CaCO}_{3}$, titanium hydride $\mathrm{TiH}_{1.92}$, and $\mathrm{Al}_{4} \mathrm{Ca}$ intermetallic compound display a small discontinuity ("pop-out") on pressure release by $80 \%$, which is 
commonly interpreted as an event of crack nucleation within an indentation of brittle material in response to the accommodation of acting indentation residual stress.

The results obtained in indentation experiments specify that crack nucleation is found to be common for all of solid materials for which plasticity characteristics are smaller than the critical value $\delta_{A} / \delta_{A}<<0.9$. In addition, under the condition above, these solid materials usually demonstrate low resistance to crack propagation. Actually, the results listed in Table 2 show that fracture toughness $K_{I c}$ of the solid materials is too small and indicative for ceramics, particularly, $\mathrm{Al}_{2} \mathrm{O}_{3}$. Moreover, the $K_{I c}$ criterion for solid materials such as $\mathrm{Al}_{4} \mathrm{Ca}, \mathrm{CaCO}_{3}$, and titanium hydride, $\mathrm{TiH}_{1.92}$ is even less than that for technical glass. This suggests that the presence of low ductile and/or brittle cell constituents can lead to impairing damage resistance of the cell walls, facilitating their premature failure under load.

\subsection{Compressive Response of Al-Foams}

Figure 4 shows representative results of compression tests for different kinds of Al-foams. All of the foams exhibit deformation patterns typical for those reported for closed-cell foams $[3,11,13,22]$.

Figure 4. Compressive stress-strain curves for (a) hydride (F1 and F3) and (b) carbonate (F2 and F4) kinds of Al-foams. Symbols L and T correspond to longitudinal and transverse tests, respectively.

(a)

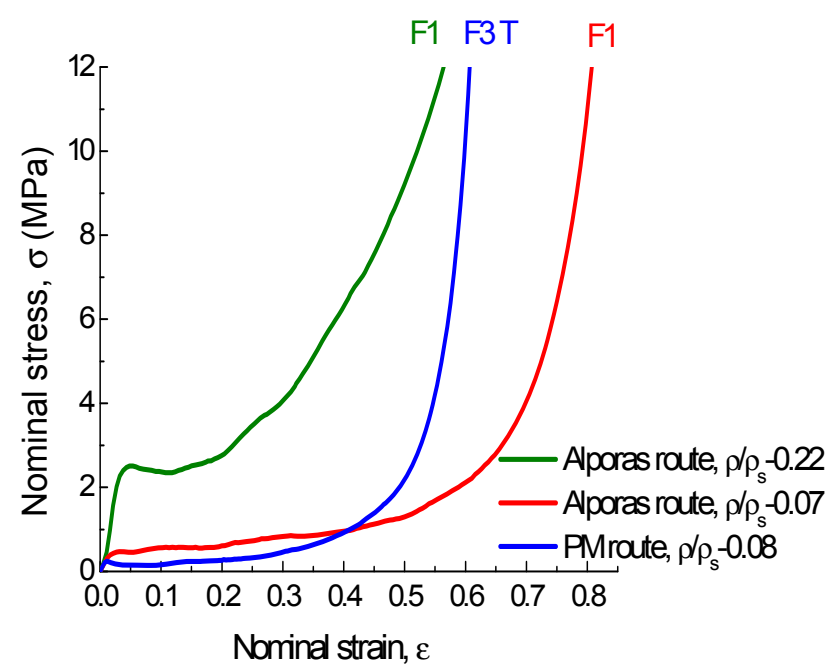

(b)

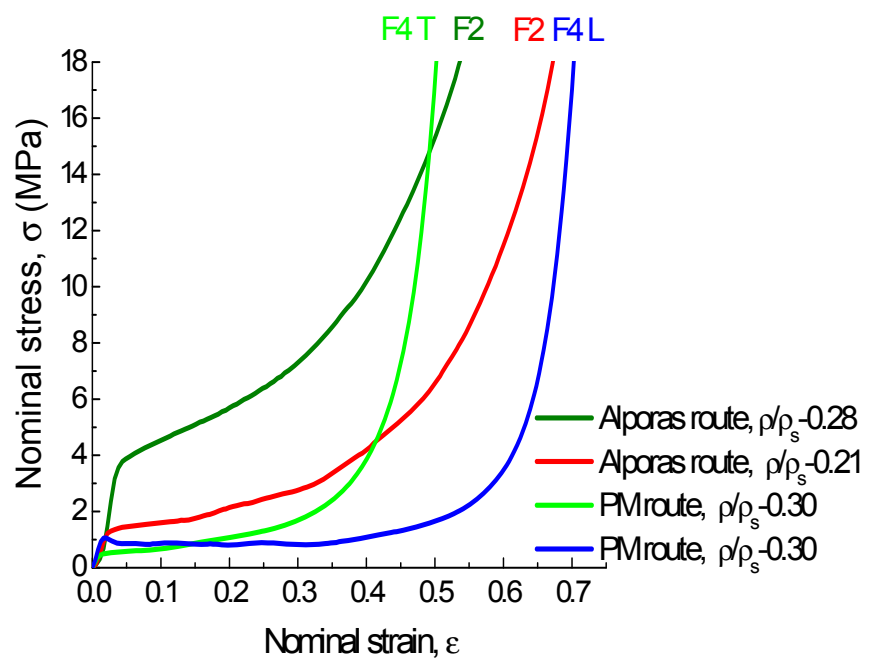

Generally, all kinds of Al-foams display an initial linear elasticity regime before general yielding (yield stress, $\sigma_{y}$ ), followed by a relatively long and well-defined "plateau" regime, which is typically associated with cell collapse, accompanied by densification of the cell wall material. The "plateau" regime continuous up to large strains (densification strain, $\varepsilon_{D}$ ) beyond which cellular structure commences to condense completely and the stress rises steeply. Typically for closed-cell foams, tensile membrane stress causes nominal stress to rise up gradually within the "plateau" regime. Additional to geometrical hardening by collapse of cells, a microscopic hardening of cell wall material by plastic deformation promotes an increase of "plateau" stress. Moreover, compressive stress decreases as relative density decreases, as depicted in Figure 4. 
As a characteristic feature related to the effect of the cell shape imperfection, anisotropy of compression response is displayed by foam F4 under longitudinal/transverse tests that is typical for Al-foams created from powder compacts [4], as can be seen in Figure 4b. A stress-strain pattern characterized by a fast hardening rate within the "plateau" regime is shown under transverse compression of foam F4 in contrast to its response under longitudinal compression at which stress-strain curve demonstrates peak stress corresponding to the onset of global collapse and followed by a load softening region to the long and almost flat "plateau".

Although all kinds of foams display a macroscopic response rather similar to elastic/plastic behavior, attention is concentrated on the differences in microscopic deformation events, as can be seen in Figure 4. A carbonate kind of Al-foam F2 with ductile eutectic domains in the cell wall material deforms smoothly throughout the entire strain range that is usually associated with plastic buckling [22]. In contrast, slight oscillations are superimposed upon an increasing "plateau" stress level in deformation patterns of all the other kinds of Al-foams (F1, F3, and F4), which cell walls contain low ductile and/or brittle constituents. These stress oscillations commonly interpreted as hardening/softening sequences are typically associated with local brittle failure of the cell walls [22]. Thus, comparative analysis of compressive response for different kinds of Al-foams elucidate the fact that microstructure and mechanical damage of cell wall constituents have a dramatic effect on the microscopic mechanism of local deformation and failure, which in turn is thought to have an influence on the macroscopic mechanical response of Al-foams.

\subsection{Comparison of Al-foam Compressive Strength with Theoretical Models}

There are several models based on the idealized representation of a defect-free cellular structure. Among them, the most famous scaling laws applied for describing mechanical properties are summarized in [11]. For open-cell foams made of elastic-plastic materials, dimensional arguments give the plastic collapse stress, $\sigma_{p l}$, relative to the yield strength of the solid cell edge material, $\sigma_{y s}$, as:

$$
\frac{\sigma_{p l}}{\sigma_{y s}}=C_{3}\left(\frac{\rho}{\rho_{s}}\right)^{3 / 2}
$$

where the constant $\mathrm{C}_{3}$ is related to the cell geometry. For a wide range of foams the constant above, $\mathrm{C}_{3}$, is roughly about 3 .

For closed-cell foams, yielding of the stretched cell faces contribute to their strength so that the additional term on right hand side appears in the relation for the plastic collapse stress:

$$
\frac{\sigma_{p l}}{\sigma_{y s}}=C_{3}\left(\frac{\rho}{\rho_{s}}\right)^{3 / 2}+C_{3}^{\prime}\left(\frac{\rho}{\rho_{s}}\right)
$$

Finite element analysis of a tetrakaidecahedral unit with flat faces gives a slightly different relation [23].

$$
\frac{\sigma_{p l}}{\sigma_{y s}}=0.33\left(\frac{\rho}{\rho_{s}}\right)^{2}+0.44\left(\frac{\rho}{\rho_{s}}\right)
$$


Generally, compressive strength is usually defined in slightly different ways in different studies, i.e., it is either "plateau" stress, relative to the yield strength, or compressive strength at $20 \%$ strain [11]. Yield stress, $\sigma_{y}$, at the general yielding, and plateau stress up, to densification, $\sigma_{p l}$, at which cellular structure commences to condense completely and the stress rises steeply [12], are used in the present study to define collapse stress and therefore estimate the role of cell wall microstructure in terms of its effect on compressive response of Al-foams.

The values of compressive strength, $\sigma_{y}$ and $\sigma_{p l}$, for the kinds of Al-foams (F1, F2, F3, and F4) studied have been normalized by the values of yield strength, $\sigma_{y s}$, for the solid alloys, the compositions for which correspond approximately to the cell wall materials. Approximate values of yield strength, $\sigma_{y s}$, for solid materials determined by conventional mechanical tests in tensile are listed in Table 3.

Table 3. Composition and yield strength, $\sigma_{y s}$, of solid materials.

\begin{tabular}{ccc}
\hline Kind of Al-foam & Composition of solid material & Yield strength, $\boldsymbol{\sigma}_{\boldsymbol{y s}}(\mathbf{M P a})$ \\
\hline $\mathrm{F} 1$ & $\mathrm{Al}+\left(\mathrm{Al}+\mathrm{Al}_{3} \mathrm{Ti}+\mathrm{Al}_{4} \mathrm{Ca}\right)$ domains & $42.80 \pm 4.89$ \\
$\mathrm{~F} 2$ & $\mathrm{Al}+\left(\mathrm{Al}+\mathrm{Al}_{4} \mathrm{Ca}\right)$ domains & $43.50 \pm 7.1$ \\
$\mathrm{~F} 3$ & $\mathrm{Al}+\left(\mathrm{Al}+\mathrm{Al}_{3} \mathrm{Ti}\right)$ domain traces & $41.00 \pm 5.4$ \\
F4 & $\mathrm{Al}+\mathrm{CaCO}_{3} / \mathrm{CaO}$ particles & $43.30 \pm 3.35$ \\
\hline
\end{tabular}

Data for the relative compressive strength, $\sigma_{y} / \sigma_{y s}$ and $\sigma_{p l} / \sigma_{\mathrm{ys}}$, for different kinds of Al-foams (F1, F2, F3, and F4) are plotted in Figure 5 along the lines, which represent Equations (1) and (2) for open- and closed-cell foams, respectively.

Figure 5. Relative compressive strength plotted against relative density for different kinds of Al-foams. Symbols L and T correspond respectively to longitudinal and transverse tests.

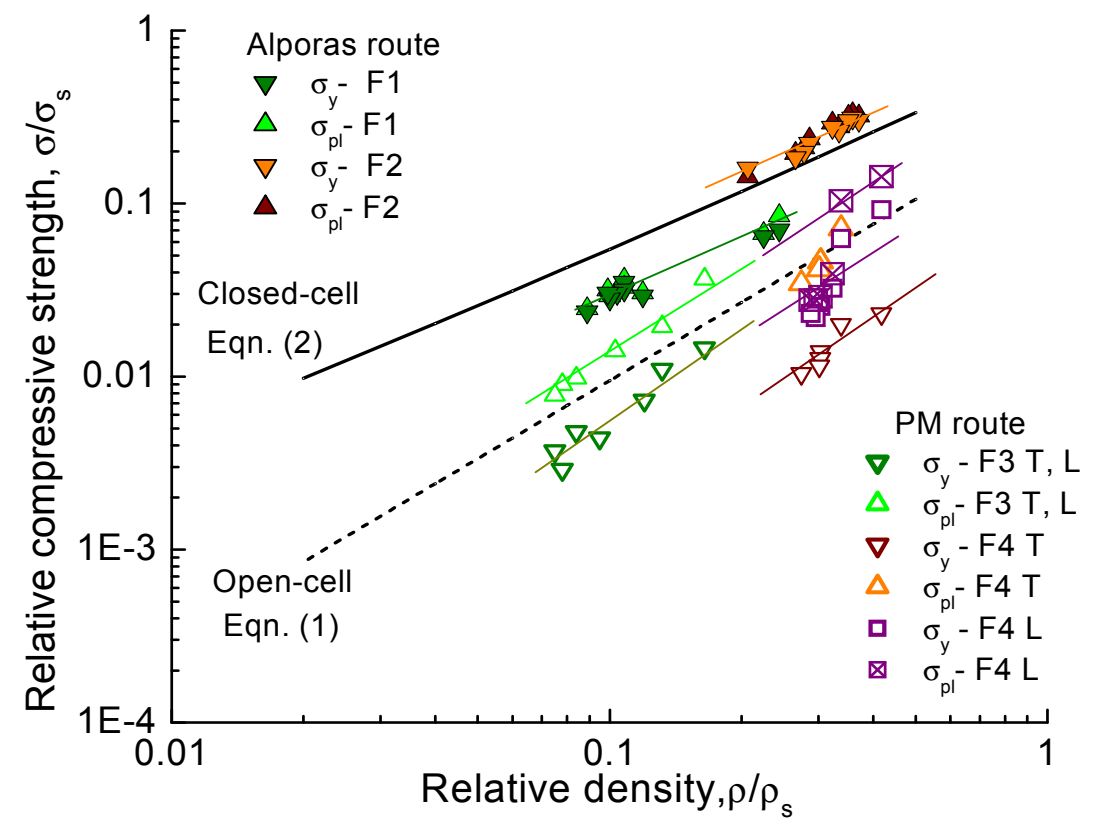

Data for the carbonate kind of Al-foam F2 performed by the Alporas route lie close to Equation (2), as prescribed by the theory for closed-cell foams. However, behavior of the hydride kind of Al-foam 
F1 produced by the same manner is rather different. Data for Al-foam F1 lie below Equation 2 and shift to Equation 3, suggesting the decreased contribution of plastic bending to the failure.

Considerable deflection of the experimental results from theoretical predictions is revealed for Al-foams produced via the PM route. Data for the hydride kind of Al-foam F3 lie well below Equation (2) and much close to Equation (1). In addition, data for plateau stress lie just above the line representing strength for open-cell foam whereas those for the yield stress lie below Equation (1). The discrepancy between Equation (2) and the data for Al-foam F4 composed of elongated cells is the mostly pronounced and dependent on loading conditions, i.e., transverse or longitudinal compression. Data for yield stress under transverse compression are found well below Equation (1), as can be seen in Figure 5. The presence of highly elliptical cells induces bending in the neighboring cell walls, initiating premature collapse of the deformation band [11,31]. However, the data for plateau stress shift essentially above the data for yield stress and lie along the line representing open-cell foam. This is because the hardening rate within the "plateau" regime under transverse compression of Al-foam F4 with highly elliptical cells is much faster compared to that under longitudinal compression, resulting in a pronounced difference between the values of compressive strength, $\sigma_{y}$ and $\sigma_{p l}$, as evidenced from Figure 4b. Again, data for yield and plateau stresses recorded under longitudinal tests are found below Equation (1). It is noticeable that the data for compressive strength derived under the longitudinal test shift upwards when relative density increases up to $\rho>0.35$, which in turn is associated with a greater thickness of the cell walls.

Generally, one or another scaling low could be adjusted to approximate compressive strength of the each kind of $\mathrm{A} 1$ foams (F1, F2, F3, and F4). The results of approximations are listed in Table 4.

Table 4. Scaling lows for approximation of the compressive strength for Al-foams.

\begin{tabular}{cccc}
\hline Foam Code & Approximation & $C_{3}$ & $C_{3}^{\prime}$ \\
\hline $\mathrm{F} 1\left(\sigma_{y} / \sigma_{y s}\right.$ and $\left.\sigma_{p} / \sigma_{y s}\right)$ & Equation (2)/Equation (3) & $0.35 / 0.33$ & $0.15 / 0.25$ \\
$\mathrm{~F} 2\left(\sigma_{y} / \sigma_{y s}\right.$ and $\left.\sigma_{p p} / \sigma_{y s}\right)$ & Equation (2)/Equation (3) & $0.25 / 0.33$ & $0.65 / 0.65$ \\
$\mathrm{~F} 3\left(\sigma_{y} / \sigma_{y s}\right)$ & Equation (3) & 0.33 & 0.02 \\
$\mathrm{~F} 3\left(\sigma_{p l} / \sigma_{y s}\right)$ & Equation (3) & 0.33 & 0.1 \\
$\mathrm{~F} 4\left(\sigma_{y} / \sigma_{y s}\right)^{(1)}$ & Equation (2) & 0.15 & 0 \\
$\mathrm{~F} 4\left(\sigma_{p l} / \sigma_{y s}\right)^{(1)}$ & Equation (2) & 0.30 & 0 \\
$\mathrm{~F} 4\left(\sigma_{y} / \sigma_{y s} \text { and } \sigma_{p l} / \sigma_{y s}\right)^{(2)}$ & Equation (2) & 0.15 & 0 \\
$\mathrm{~F} 4\left(\sigma_{y} / \sigma_{y s}\right)^{(3)}$ & Equation (2) & 0.30 & 0.10 \\
$\mathrm{~F} 4\left(\sigma_{p l} / \sigma_{y s}\right)^{(3)}$ & Equation (2) & 0.33 & 0.10 \\
\hline
\end{tabular}

Note: ${ }^{(1)}$ : transverse compression of Al-foam with $\rho / \rho_{\mathrm{s}}<0.35 ;{ }^{(2)}$ : longitudinal compression of Al-foam with $\rho / \rho_{\mathrm{s}}<0.35 ;^{(3)}$ : longitudinal compression of Al-foam with $\rho / \rho_{\mathrm{s}}>0.35$.

The compressive strength of two kinds of Al-foams (F1, F2), performed by the Alporas route, complies with relations prescribed by Equations (2) and (3) for closed-cell structures. It is noticeable that the value of the numerical coefficient $C_{3}^{\prime}$ for the hydride kind of Al-foam F1 is reduced to $23 \%$ (Equation (2)) or 38\% (Equation (3)) of the value $C_{3}^{\prime}$ for the carbonate kind of Al-foam F2, which in turn is associated with a contribution of fracture mode in the collapse of deformation bands. The latter suggestion is thought to be true for other kinds of Al-foams (F3, F4) fabricated via the PM route. For 
these kinds of Al-foams, strength degradation caused by reducing the numerical coefficient $C_{3}^{\prime}$ down to absolute disappearance is found, as can be seen in Table 4.

Thus, a different micromechanism for the collapse of deformation bands could be assumed by considering the characteristic features of microstructure and, especially, mechanical damage of the cell wall constituents contained by the cell walls of different kinds of A1-foams (F1, F2, F3, and F4), which have been given in the previous subsection 2.2 .

\subsection{Correlation of Al-foam Compressive Response and Damage Behavior of Cell Wall Constituents}

Plastic collapse of deformation bands indicative of carbonate kind of Al-foam F2 is reasonably expected because $\mathrm{Al}+\mathrm{Al}_{4} \mathrm{Ca}$ eutectic domains contained by the cell walls give the value of plasticity characteristic, $\delta_{\mathrm{A}}=0.90$, quite sufficient for material plastic behavior, the same as for the ductile Al-matrix, for which $\delta_{\mathrm{A}}=0.96$, as can be seen in Table 2 . The contribution of fracture mode in the collapse of deformation bands is indicative of a hydride kind of Al-foam F2, in which cell walls contain brittle $\mathrm{Al}+\mathrm{Al}_{4} \mathrm{Ca}+\mathrm{Al}_{3} \mathrm{Ti}$ eutectic domains for which parameter $\delta_{\mathrm{A}}$ is about 0.72 (see Table 2). Small deflections in the cell walls lead to formation of cracks which propagate through the $\mathrm{Al}+\mathrm{Al}_{4} \mathrm{Ca}+\mathrm{Al}_{3} \mathrm{Ti}$ eutectic domains, finally cause the crushing of the cells under compression, as shown in Figure $6 \mathrm{a}$. Slight oscillations superimposed upon "plateau" stress reflect local fracture of the deformation bands, as shown in Figure 4.

In Al-foams (F3 and F4) fabricated via the PM route, brittle cell wall constituents such as either Ti-rich particles rounded by a $\mathrm{Al}_{3} \mathrm{Ti}$ layer and smaller $\mathrm{Al}_{3} \mathrm{Ti}$ particles, or $\mathrm{CaCO}_{3} / \mathrm{CaO}$ particles, act as likely sites for the initiation of cracks, the propagation of which generates stress concentration in adjacent areas, intervening the Al-matrix. the final failure of the cell walls apparently occurs by crushing the brittle cell constituents and their bridging across intact ligaments, as can be seen in Figure 6b. Again, local fracture of the deformation bands causes oscillations of "plateau" stress, as shown in Figure 4.

Figure 6. SEM images of cracks in the cell walls of Al-foams (a) F1 and (b) F3.

(a)

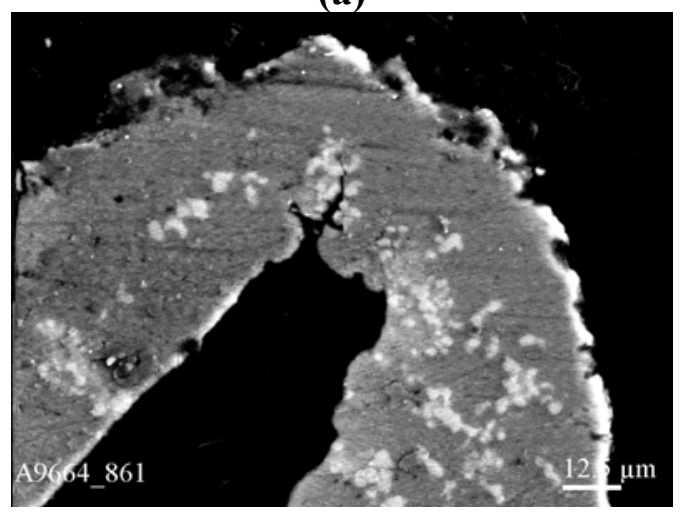

(b)

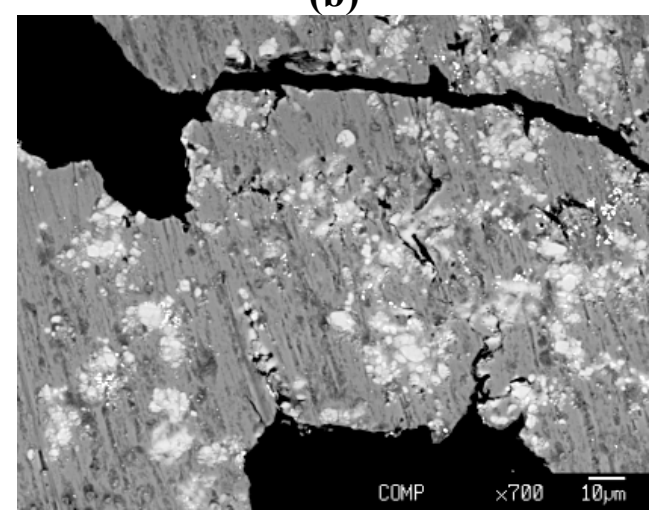

It could be assumed that the presence of brittle constituents in the cell wall of closed-cell Al-foams (F3 and F4) induces the collapse of deformation bands by crushing, thus reducing their strength properties to values close or even below those of open-cell foams of the same relative density, as shown in Figure 5. The dramatic degradation of the mechanical behavior of Al-foams fabricated via 
the PM route results from the increased fraction volume of brittle particles in the cell wall material, e.g., for the hydride kind of Al-foam F3 yield strength, $\sigma_{y}$, is $20 \%$ and plateau stress, $\sigma_{p l}$, is $43 \%$ of those for the hydride kind of Al-foam F1 of the same relative density. about $\rho / \rho_{\mathrm{s}} \approx 0.9$.

Differences in micro-mechanisms of deformation discussed above hold the key to a greater understanding of the role of cell wall constituents in terms of their effect on the macroscopic response of Al-foams. Collapse stress, which Al-foams can undergo up to densification, is proved to be actually very sensitive to small defects induced by crushed brittle constituents in the cell wall microstructure. That is why the experimental data reported in literature for strength properties of closed-cell foams, whose cell walls contain brittle constituents, are found to be systematically lower than those predicted by theoretical models [11]. Attention should be drawn to the fact that the effect of brittle constituents in the cell wall material on degradation of strength properties is much stronger and comparable with that implemented by decreasing the relative density of intact Al-foam that is free of defects, as can be seen in Figure 5.

As applied for engineering practice, the carbonate kind of Al-foam F2 fabricated via the Alporas route shows indisputable advantages in virtually all aspects of its application. Besides economical advantages provided by using inexpensive $\mathrm{CaCO}_{3}$ as an alternative foaming agent, the design of structural elements comprising this kind of Al-foam becomes easier because of reliable calculations of strength. In addition, uniform collapse of this Al-foam over the entire range of loading conditions is preferable in practical applications where an effective utilization of impact energy combined with damage tolerance is required.

\section{Experimental}

\subsection{Materials and Experimental Procedure}

Several kinds of closed-cell foams denoted as F1, F2, F3, and F4 and used in experimentation are listed in Table 5.

Table 5. Characteristics for different kinds of Al-foams.

\begin{tabular}{llll}
\hline Code & Process & Processing additives & Relative density $\left(\rho / \rho_{s}\right)^{(1)}$ \\
\hline F1 & Alporas route & $1 \mathrm{wt} . \% \mathrm{Ca}+1 \mathrm{wt} . \% \mathrm{TiH}_{2}$ & $0.371-0.207$ \\
F2 & Alporas route & $1 \mathrm{wt} . \% \mathrm{Ca}+2 \mathrm{wt} . \% \mathrm{CaCO}_{3}$ & $0.244-0.089$ \\
F3 & PM technique & $2 \mathrm{wt.} \% \mathrm{TiH}_{2}$ & $0.165-0.075$ \\
F4 & PM technique & $2 \mathrm{wt} . \% \mathrm{CaCO}_{3}$ & $0.418-0.274$ \\
\hline \multicolumn{4}{r}{ Note $^{(1)}: \rho$ and $\rho_{s}$ correspond the density of foam and solid, respectively. }
\end{tabular}

Two kinds of Al-foams (F1 and F2) were produced with pure Al (purity 99.95\%) via an Alporas-like route [32] in which calcium (1 wt.\%) was firstly introduced into molten Al to enhance its viscosity and, then, either powdered titanium hydride, $\mathrm{TiH}_{2},(1 \mathrm{wt} . \%)$ or powdered calcium carbonate, $\mathrm{CaCO}_{3}$, (2 wt.\%), as an alternative foaming agent [8-10,33] were added by vigorous stirring to produce the foams (respectively, F1, F2 and F2, F3). Prior adding of $\mathrm{CaCO}_{3}$ powder was coated with $\mathrm{CaF}_{2}$ by the ion-exchange method $[9,10]$ to facilitate its dispersion within the melt. The other two foams (F3 and F4) were made by a powder metallurgical (PM) route $[9,10,12,18]$ in which water 
atomized Al-powder (oxygen content $0.3 \mathrm{wt} \%$ ) with particle size $160 \mu \mathrm{m}$ and less was firstly mixed either with $\mathrm{TiH}_{2}(2 \mathrm{wt} . \%)$ or $\mathrm{CaCO}_{3}(2 \mathrm{wt} . \%)$ and then pre-compacted, extruded into precursor, and finally foamed by heating. Powdered titanium hydride $\mathrm{TiH}_{2}$ with a mean particle size of $60 \mu \mathrm{m}$ and powdered calcium carbonate $\mathrm{CaCO}_{3}$ with a mean particle size of $8 \mu \mathrm{m}$ were employed in the Alporas process and PM route.

Several solid materials compositionally corresponding to the cell wall constituents listed in Table 1 were used to quantify their mechanical response. Calcium carbonate, $\mathrm{CaCO}_{3}$, was produced by marble plate, while intermetallic compounds, such as $\mathrm{Al}_{3} \mathrm{Ti}$ and $\mathrm{Al}_{4} \mathrm{Ca}$, were produced by an arc-melting technique. Dense bulk titanium hydride was fabricated via powder compact route. Powdered titanium hydride with a composition $\mathrm{TiH}_{1.92}$, and particle size about $60 \mu \mathrm{m}$, was firstly pre-compacted, and then subjected to hydrostatic compression under high pressure of about $6 \mathrm{GPa}$.

In addition, several solid materials compositionally corresponded to those formed in the cell wall materials of the studied kinds of Al-foams were fabricated either via casting or PM routes, as listed in Table 6. Approximated values of yield strength for these solid materials were determined by conventional mechanical tests in tensile to use them as input data in theoretical models for interpreting the behavior of foam under compression.

Table 6. Characteristics of solid materials.

\begin{tabular}{ccc}
\hline No & Raw materials & Process \\
\hline 1 & $\mathrm{Al}+1 \mathrm{wt} . \% \mathrm{Ca}+1 \mathrm{wt.} \% \mathrm{Ti}$ & Casting \\
2 & $\mathrm{Al}+1 \mathrm{wt} . \% \mathrm{Ca}$ & Casting \\
3 & $\mathrm{Al}$ alloy powder doped with $2 \mathrm{wt} \% \mathrm{Ti}$ & Hot extrusion \\
4 & Powdered mixture of $\mathrm{Al}+2 \mathrm{wt} . \% \mathrm{CaCO}_{3}$ & Hot extrusion \\
\hline
\end{tabular}

\subsection{Structural Characterization}

All of the Al-foams were characterized by their relative density $\rho / \rho_{s}$ (where $\rho$ and $\rho_{s}$ correspond to the density of foam and solid, respectively), cell morphology and cell microstructure. Relative density, $\rho / \rho_{s}$, was measured by weighing a sample of known volume. Cell morphology, including cell size and shape, was studied by using scanned images of more than 150 cells. Microstructure examination was performed using X-Ray diffraction (XRD) analysis and scanning electron microscopy (SEM) in both secondary and back-scattered modes. Elementary composition was studied using energy dispersive $\mathrm{X}$-Ray spectroscopy (EDS) and electron probe microanalysis (EPMA).

\subsection{Mechanical Testing}

Deformation behavior of Al-foams was examined under uniaxial compressive tests performed on prismatic specimens with a ratio of height to thickness that exceeds 1.5 . The minimum dimension of the specimen in the each of three directions was seven times more than the cell size to avoid size effect. The compression tests were performed on a servo-hydraulic testing machine under displacement control and static strain rate of $1.5 \times 10^{-3} \mathrm{~s}^{-1}$. 


\subsection{Indentation Experiments}

Mechanical response of the cell wall constituents and solid materials was examined by indentation technique. In experiments with foams, a maximum indentation depth was set to be at least 10 times at the least than the typical cell wall thickness. A Nano Indenter II $^{\circledR}$ tester, equipped with a trihedral Berkovich pyramid with a tip angle $\gamma_{1}=65^{\circ}$ as well as a conventional microhardness machine equipped with tetrahedral Vickers pyramid with a tip angle $\gamma_{1}=68^{\circ}$ were used in indentation experiments. In addition, a set of nine trihedral diamond pyramids with tip angles $\gamma_{1}$ ranging from $45^{\circ}$ to $85^{\circ}$ was used in experimentation with the conventional microhardness machine.

Vickers hardness $\mathrm{HV}$ was determined under loads higher than critical value $F \geq F_{\mathrm{c}}$ to avoid uncertainty in measurements caused by size effect [34]. Overall, indentation loads used for measuring Vickers hardness were not less than $0.1 \mathrm{~N}$. Moreover, the final Vickers hardness value was averaged over the data determined by measuring not less than 10 indentations under each indentation load. The plasticity characteristic $\delta_{H}$, a dimensionless parameter, that can vary between 0 ("pure" elastic contact) to 1 ("pure" plastic contact) was derived by calculations through microhardness measurement results and Young's modulus, E, according to the test method procedure proposed originally by Milman et al. [28]. Young's modulus, $E$, and nanohardness, $H_{h}$, were derived from load-displacement data recorded in nanoindentation experiments using the technique originally proposed by Oliver and Pharr [35]. In addition, the plasticity characteristic $\delta_{A}$, which is physically close to that denoted by $\delta_{H}$, was derived from loading and unloading data according to the demands of International standard ISO 14577-1:2002 (E) according to the test method procedure published in [36].

Yield stress, $\sigma_{y s}$, was extracted from the 'stress-strain' curve constructed by using microhardness measurement results determined by a set of trihedral pyramids with different tip angles $\gamma_{1}$ (ranging from $45^{\circ}$ to $85^{\circ}$ ) according to the test method procedure [37]. As was found previously, the angle at the pyramid tip, $\gamma_{1}$, mainly defines the strain over indentation (average strain on the contact area of the indenter with indented solid in the loading direction), i.e., $\varepsilon \approx-\ln \sin \gamma_{1}$ [30,38]. Fracture toughness $K_{I c}$ of the solid materials was determined by using radial indentation cracks [38,39].

Atomic forced microscopy (AFM) was used to recognize characteristic features of mechanical damage within and around indentations placed on tested materials.

\section{Conclusions}

Distinguishing characteristics of the microstructure for several kinds of closed-cell Al-foams produced with pure Al by the Alporas melt process (F1, F2) and powder metallurgical (PM) technique (F3, F4), all performed either with titanium hydride, $\mathrm{TiH}_{2}$, (F1, F3) or with calcium carbonate, $\mathrm{CaCO}_{3}$, (F2, F4) as an alternative foaming agent, were studied and classified. When the Alporas route is used the cell walls of the hydride kind of Al-foam $\mathrm{F} 1$ contain a network of $\mathrm{Al}+\mathrm{Al}_{4} \mathrm{Ca}+\mathrm{Al}_{3} \mathrm{Ti}$ eutectic domains and incorporate Al-Ca-Ti particles, whereas those of the carbonate kind of Al-foam F2 comprise $\mathrm{Al}+\mathrm{Al}_{4} \mathrm{Ca}$ eutectic domains. A fine $\mathrm{Al}_{2} \mathrm{O}_{3}$ network being left by broken oxide skin presented around $\mathrm{Al}$ powder particles are typically presented in the cell walls of both kinds of Al-foams (F3, F4) produced by the PM route. Besides trace amounts of $\mathrm{Al}+\mathrm{Al}_{3}$ Ti eutectic domains, a lot of particles/layers of $\mathrm{Al}_{3} \mathrm{Ti}$ intermetallic compound, as well as large particles of partially reacted 
$\mathrm{TiH}_{2}$ are embedded in the cell walls of the hydride kind of $\mathrm{Al}$-foam $\mathrm{F} 3$ while $\mathrm{CaO} / \mathrm{CaCO}$ particles survive in the cell wall material of carbonate kind of Al-foam F4.

A set of mechanical characteristics for materials, compositionally corresponding to the cell wall constituents of different kinds of Al-foams, was tested and exhaustively specified. Young's modulus, $E$, Vickers hardness, $H V$, nanohardness $H_{h}$, plasticity characteristics $\delta_{H}$ and $\delta_{A}$, as well as fracture toughness $K_{I c}$, were determined in indentation experiments. The plasticity characteristic, $\delta_{A}$, for $\mathrm{Al}+\mathrm{Al}_{4} \mathrm{Ca}$ eutectic domains was found to be of critical value 0.90 , suggesting the ductile behavior of the material. The opposite is true for $\mathrm{Al}+\mathrm{Al}_{4} \mathrm{Ca}+\mathrm{Al}_{3} \mathrm{Ti}$ eutectic domains and the other compounds such as $\mathrm{Al}_{3} \mathrm{Ti}, \mathrm{Al}_{4} \mathrm{Ca}, \mathrm{TiH}_{2}, \mathrm{CaO}, \mathrm{CaCO}_{3}, \mathrm{Al}_{2} \mathrm{O}_{3}$, for which the plasticity characteristic, $\delta_{A}$, was found to be much smaller than critical value, $\delta_{A}=0.72$, implying their low ductility and tendency to fracture. Actually, fracture toughness $K_{I c}$ for all of the latter compounds was found to be very small and typical for ceramics. In addition, strong localized deformation in shear bands of $\mathrm{Al}_{3} \mathrm{Ti}$ and $\mathrm{CaCO}_{3}$ compounds contribute directly in their mechanical damage, facilitating the crack nucleation by ductile cleavage.

Differences in the macroscopic compressive response of different kinds of Al-foams were studied and clarified $v s$. mechanical damage of the cell wall constituents. The latter substantially affects the micro-mechanism of deformation. Homogeneous plastic collapse of deformation bands over the entire range of loading conditions is ensured by ductility of $\mathrm{Al}+\mathrm{Al}_{4} \mathrm{Ca}$ eutectic domains contained by the cell walls of the carbonate kind of Al-foam F2, whereas the contribution of fracture mode is favored by low ductile $\mathrm{Al}+\mathrm{Al}_{3} \mathrm{Ti}+\mathrm{Al}_{4} \mathrm{Ca}$ eutectic domains contained by the cell walls of Al-foam $\mathrm{F} 1$ as well as by brittle particles/layers such as $\mathrm{Al}_{3} \mathrm{Ti}, \mathrm{TiH}_{2}, \mathrm{CaO} / \mathrm{CaCO}_{3}$, and the fine $\mathrm{Al}_{2} \mathrm{O}_{3}$ network presented in the cell walls of PM Al-foams F3 and F4. These low ductile and/or brittle constituents act as likely sites for crack nucleation, the propagation of which leads to local fracture of the deformation band, thus resulting in oscillations of "plateau" stress.

Considerable deflection of the experimental results from theoretical predictions based on an idealized representation of cellular structure was revealed in the presence of low ductile and/or brittle constituents contained by the cell walls of Al-foams (F1, F3, and F4). The collapse of deformation bands by crushing leads to a reduction of their strength properties to values close or even below to those for open-cell foams of the same relative density. A degradation of strength properties becomes especially pronounced with increases in the fraction volume of brittle constituents in the cell wall microstructure of Al-foams (F3 and F4) performed by the PM route. Moreover, the presence of elliptical cells leads to an additional reduction of the strength of Al-foam F4 under a transverse compressive test.

Correlations of relative compressive strength, $\sigma / \sigma_{y s}$, versus relative density $\rho / \rho_{s}$, were obtained in the form prescribed by theoretical models for closed-cell foams. Discrepancies between experimental results and theoretical predictions were compensated by variations in the values of numerical coefficients $C_{3}$ and $C_{3}^{\prime}$ placed at the terms related respectively to the influence of relative density and yielding of the stretched cell faces. Reducing the numerical coefficient $C_{3}^{\prime}$ down to a negligible value was found by increasing the fraction volume of brittle constituents in the cell walls of Al-foams (F3 and F4) performed by the PM route.

The results of the present study hold the key to a greater understanding of the interplay between processing conditions, cell wall microstructure, damage behavior of the cell wall constituents, and mechanical response of Al-foams. 


\section{Acknowledgements}

The research was partly supported by the National Academy of Sciences of Ukraine, Project No. III-3-10. The authors are thankful to Y. Milman for fruitful discussions as well as to S. Dub for nanoindentation experiments and to $\mathrm{D}$. Verbilo for help with compression tests.

\section{References}

1. Markaki, A.E.; Clyne, T.V. Characterization of impact response of metallic foam/ceramic laminates. Mater. Sci. Technol. 2000, 16, 785-791.

2. Crupi, V.; Epasto, G.; Guglielmino, E. Impact response of aluminum sandviches for light-weight ship structures. Metals 2011, 1, 98-112.

3. Ashby, M.F.; Evans, A.G.; Fleck, N.A.; Gibson, L.J. Metal Foams: A Design Guide; Butterworth-Heinemann Press: Waltham, MA, USA, 2000.

4. Banhart, J. Manufacture, characterisation and application of cellular metals and metal foams. Prog. Mater. Sci. 2001, 46, 559-632.

5. Neugebauer, R.; Hipke, J.; Hohlfeld, T.; Thummler, R. Highly damped machine tools with metal foam. In Proceedings of the International Conference Advanced metallic materials, Smolenice Castle, Slovakia, 5-7 November 2003; Jerz, J., Ed.; Institute of Materials and Machine Mechanics: Smolenice, Slovakia, 2003; pp. 214-218.

6. Nakamura, T.; Gnyloskurenko, S.V.; Sakamoto, K.; Byakova, A.V.; Ishikava, R. Development of new foaming agent for metal foam. Mater. Trans. 2002, 43, 1191-1196.

7. Gergely, V.; Curran, D.C.; Clyne, T.W. The FOAMCARP process: Foaming of aluminum MMCs by the chalk-aluminum reaction in precursor. Compos. Sci. Technol. 2003, 63, 2301-2310.

8. Byakova, A.V.; Gnyloskurenko, S.V.; Maeda, M.; Nakamura, T.; Sakamoto, K.; Podrezov, Y.N.; Ishikawa, R. Development of lightweight Al alloy and technique. Can. Metall. Q. 2005, 44, 7-12.

9. Byakova, A.V.; Sirko, A.I.; Mykhalenkov, K.V.; Milman, Y.V.; Gnyloskurenko, S.V.; Nakamura, T. Progress in aluminum foam technique: Application of the carbonate foaming agent for Alporas and powder compact routes. In Porous Metals and Metal Foaming Technology; Nakajima, H., Kanetake, N., Eds.; JIM Press: Tokyo, Japan, 2005; pp. 273-278.

10. Byakova, A.V.; Sirko, A.I.; Mykhalenkov, K.V.; Milman, Y.V.; Gnyloskurenko, S.V.; Nakamura, T. Improvements in stabilisation and cellular structure of Al based foams with novel carbonate foaming agent. High Temp. Mater. Processes. 2007, 26, 239-245.

11. Gibson, L.J. Mechanical behavior of metallic foams. Annu. Rev. Mater. Sci. 2000, 30, 191-227.

12. Milman, Y.; Byakova, A.; Podrezov, Y.; Verbilo, D.; Nakamura, T. The effect of processing route on the energy management of foamed Al alloys. In Porous Metals and Metal Foaming Technology; Nakajima H., Kanetake N., Eds.; JIM Press: Tokyo, Japan, 2005; pp. 503-508.

13. Markaki, A.E.; Clyne, T.W. The effect of cell wall microstructure on the deformation and fracture of aluminum-based foams. Acta mater. 2001, 49, 1677-1686.

14. Milman, Y.; Byakova, A.; Sirko, A.; Gnyloskurenko, S.; Nakamura, T. Improvement of structure and deformation behavior of high-strength Al-Zn-Mg foams. Mater. Sci. Forum 2006, 519-521, 573-578. 
15. Miyoshi, T.; Mukai, T.; Hihashi, K. Energy absorption in closed-cell Al-Zn-Mg-Ca-Ti foam. Mater. Trans. 2002, 43, 1778-1781.

16. Toda, H.; Kuroda, N.; Ohgaki, T. Image-based mechanical analysis of dynamic deformation and damage behaviors in an aluminum foam using synchrotron X-ray microtomography. In Porous Metals and Metal Foaming Technology; Nakajima H., Kanetake N., Eds.; JIM Press: Tokyo, Japan, 2005; pp. 409-414.

17. Sugimura, Y.; Meyer, J.; He, M.Y. On mechanical performance of closed cell Al alloy foams. Acta Mater. 1997, 45, 5245-5259.

18. Byakova, A.; Gnyloskurenko, S.; Sirko, A.; Milman, Y.; Nakamura, T. The role of foaming agent in structure and mechanical performance of Al based foams. Mater. Trans. 2006, 47, 2131-2136.

19. Gnyloskurenko, S.V.; Byakova, A.V.; Sirko, A.I.; Dudnyk, A.O.; Milman, Y.V.; Nakamura, T. Advanced structure and deformation pattern of Al based alloys foamed with calcium carbonate agent. In Metals and Melt Foaming Technology, Proceedings of 5th International Conference Porous Metals and Metallic Foams, Montreal, PQ, Canada, 5-7 September 2007; DEStech Publications, Inc.: Lancaster, USA, 2007; pp. 399-402.

20. Markaki, A.E.; Clyne, T.V. Characterization of impact response of metallic foam/ceramic laminates. Mater. Sci. Technol. 2000, 16, 785-791.

21. Crupi, V.; Epasto, G.; Guglielmino, E. Low velocity impact strength of sandwich materials. J. Sandw. Struct. Mater. 2011, 17, 32-41.

22. Gibson, L.G.; Ashby, M.F. Cellular Solids: Structure and Properties; Pergamon Press: New York, NY, USA, 1988.

23. Simone, A.E.; Gibsons, L.J. The effect of cell face and corrugations on the stiffness and strength of metallic foams. Acta Mater. 1998, 46, 3929-3935.

24. Kriszt, B.; Foroughi, B.; Faure, K.; Degisher, H.P. Behavior of aluminum foam under uniaxial compression. Mater. Sci. Technol. 2000, 16, 792-796.

25. Harders, H.; Huper, K.; Rosler, J. Influence of cell wall shape and density on mechanical behavior of $2 \mathrm{~d}$ foam structures. Acta Mater. 2005, 53, 1335-1345.

26. Jeon, I.; Asahina, T. The effect of structural defects on the compressive behavior of closed-cell Al foam. Acta Mater. 2005, 53, 3415-342.

27. Milman, Y.V.; Miracle, D.B.; Chugunova, S.I.; Voskoboinik, I.V.; Korzhova, N.P.; Legkayaa, T.N.; Podrezova, Y.N. Mechanical behavior of $\mathrm{Al}_{3} \mathrm{Ti}$ intermetallic and $\mathrm{L}_{2}$ phases on its basis. Intermetallics 2001, 9, 839-845.

28. Milman, Y.V.; Galanov, B.A.; Chugunova, S.I. Plasticity characteristic obtained through hardness measurement. Acta Metall. Mater. 1993, 41, 2523-2532.

29. Wu, C.C.; Rice, R.W. Porosity dependence of wear and other mechanical properties of fine-grain $\mathrm{Al}_{2} \mathrm{O}_{3}$ and $\mathrm{B}_{4}$ C. Ceram. Eng. Sci. Proc. 1985, 6, 977-994.

30. Hainsworth, V.; Whitehead, A.J.; Page, T.F. The nanoindentation response of silicon and related isostructural materials. In Plastic Deformation of Ceramics; Bradt, R.C., Brookes, C.A., Routbort, J.L., Eds.; Plenum Press: New York, NY, USA, 1995.

31. Bart-Smith, H.; Bastawros, A.F.; Mumm, D.R.; Evans, A.G.; Sypeck, D.J.; Wadley, H.N.G. Compressive deformation and yielding mechanisms in cellular Al alloys determined using X-ray tomography and surface strain mapping. Acta Mater. 1998, 46, 3583-3592. 
32. Akiyama, S.; Ueno, H.; Imagawa, K.; Kitahara, A.; Nagata, S.; Morimoto, K.; Nishikawa, T.; Itoh, M. Foamed Metal and Method of Producing Same. U.S. Patent 4,713,277, 15 December 1987.

33. Nakamura, T.; Gnyloskurenko, S.V.; Sakamoto, K.; Byakova, A.V.; Ishikawa, R. Development of new foaming agent for metal foam. Mater. Trans. 2002, 43, 1191-1196.

34. Byakova, A.V.; Milman, Yu.V.; Vlasov, A.A. Application of plasticity characteristic determined by indentation technique for evaluation of mechanical properties of coatings: I. specific features of test method procedure. Sci. Sinter. 2004, 36, 27-41.

35. Oliver, W.C.; Pharr, G.M. An improved technique for determining hardness and elastic modulus using load and displacement sencing indentation experiments. J. Mater. Res. 1992, 7, 1564-1583.

36. Milman, Y.V.; Dub, S.; Golubenko, A. Plasticity characteristic obtained trough instrumental indentation. Mater. Res. Soc. Symp. Proc. 2008, 1049, 123-128.

37. Galanov, B.A.; Milman, Y.V.; Chugunova, S.I.; Goncharova, I.V. Investigation of mechanical properties high hardness materials by indentation. Superhard Mater. 1999, 21, 23-39.

38. Evans, A.G.; Charles, E.A. Fracture toughness determinations by indentation J. Ame. Ceram. Soc. 1976, 59, 371-372.

39. Niihara, K.; Morena, R.; Hasselman, D.P. Evaluation of stress intensity factor of brittle solids by the indentation method with low crack-to-indent rations. J. Mater. Sci. Lett. 1982, 1, 13-16.

(C) 2012 by the authors; licensee MDPI, Basel, Switzerland. This article is an open access article distributed under the terms and conditions of the Creative Commons Attribution license (http://creativecommons.org/licenses/by/3.0/). 